\title{
Analisis Geometri Bangunan Terhadap Kinerja Seismik Menggunakan Direct Displacement Based Design Method
}

\author{
Andi Susilo KARTIKO ${ }^{1}$, Indra KOMARA ${ }^{1 *}$, Yanisfa SEPTIARSILIA ${ }^{1}$, \\ Dita Kamarul FITRIA ${ }^{1}$, Heri ISTIONO ${ }^{1}$, Dewi PERTIWI ${ }^{1}$ \\ ${ }^{1}$ Institut Teknologi Adhi Tama Surabaya, email: indrakomara@itats.ac.id
}

\author{
Sejarah artikel \\ Diserahkan: $\quad 12$ Agustus 2021 \\ Dalam bentuk revisi: 1 September 2021
}

\author{
Diterima: $\quad 2$ September 2021 \\ Tersedia online: $\quad 30$ September 2021
}

\begin{abstract}
Seismic evaluation of the behavior of irregular structures is an important parameter, especially to determine the failure that occurs in the structure. The irregularity parameters can be in the form of nonuniform structural elevations, plans that have an unusual shape which has a different center of mass and stiffness as well as the types and dimensions of the installed structural elements. Such irregularities are often unavoidable due to architectural factors. In this study, various forms of structural irregularities will be evaluated analytically and numerically. Evaluation of the structure using the direct displacementbased design method with the ATC-40 approach is simulated to determine the performance parameters of the structure. One regular building and three irregular buildings will be evaluated and compared one and another. Based on the conducted evaluation, the building's performance value relatively meets the $D D B D$ required standard with the performance level in the state of life safety and intermediate occupancy for the ATC-40 approach.
\end{abstract}

Keywords: structural irregularities, direct displacement based design, seismic performance, numerical modeling, displacement

\begin{abstract}
Abstrak
Evaluasi seismik terhadap perilaku struktur tidak beraturan merupakan parameter penting khususnya untuk mengetahui kegagalan yang terjadi pada struktur. Parameter ketidakberaturan tersebut dapat berupa elevasi struktur yang tidak seragam, denah yang memiliki bentuk tidak umum yang mana memiliki pusat massa dan kekakuan yang berbeda serta jenis dan dimensi dari elemen struktur terpasang. Ketidakberaturan tersebut sering tidak dapat dihindari karena faktor arsitektur. Pada studi ini, akan dievaluasi berbagai bentuk ketidakberaturan struktur bangunan yang dievaluasi secara analitis dan numerik. Evaluasi struktur menggunakan metode direct displacement-based design dengan pendekatan ATC-40 disimulasikan untuk mengetahui parameter kinerja struktur. Satu bangunan regular dan tiga bangunan ireguler akan dievaluasi dan dibandingkan satu sama lain. Berdasarkan evaluasi yang dilakukan, nilai kinerja bangunan secara relatif memenuhi standar acuan DDBD dengan tingkat level kinerja berada pada life safety dan intermediate occupancy untuk pendekatan dengan ATC-40.
\end{abstract}

Kata kunci: ketidakberaturan struktur, direct displacement based design, kinerja seismik, permodelan numerik, displacement

\section{Pendahuluan}

Perilaku elastik pada struktur bangunan gedung pada umumnya dikontrol dengan beberapa parameter penentu, yaitu akibat pengaruh konfigurasi bentuk bangunan, kekakuan, kekuatan dan daktilitas (Wisnumurti, 2013). Parameter tersebut akan menentukan kapasitas bangunan secara menyeluruh khususnya parameter seismik. Dengan seiringnya perkembangan 
infrastruktur bangunan gedung, faktor konfigurasi bentuk menjadi parameter tambahan sebagai pertimbangan fungsi, terbatasnya lahan dan desain. Sehingga konfigurasi irregular building (IB) akan menjadi salah satu alternatif untuk diaplikasikan (Prakosa \& Wibowo, 2018; Wijaya dkk., 2013).

Beberapa wilayah di Indonesia, khususnya di kota- kota besar bentuk IB sudah banyak diaplikasikan untuk berbagai jenis fungsi bangunan. Kemudian, faktor desain adalah salah satu faktor yang menentukan implementasi struktur bangunan tersebut. Menurut Wijaya (2013), konsep IB dibagi menjadi dua tipe yaitu bentuk dengan pola murni / sederhana, tanpa adanya penambahan variasi pola beragam. Salah satu contoh bentuk pola murni adalah bentuk persegi, segi enam, segitiga, trapesium dan lainnya. Sedangkan, pola kompleks merupakan penggabungan beberapa pola murni yang menghasilkan variasi pola bentuk. Seperti bentuk L, T, U, V, dan lainnya (Hirde \& Aher, 2016; Kumar dkk., 2020). Walaupun banyak parameter lain yang akan mempengaruhi perilaku struktur seperti penggunaan material yang mana disampaikan sesuai beberapa studi pendahulu (Komara dkk., 2018; Komara dkk., 2019; Komara, Taşkin, dkk., 2017; Komara, Wahyuni, dkk., 2017; Nareswarananindya dkk., 2021; Susanti dkk., 2021), konsep desain dan tinjauan elemenpun menjadi faktor pendukung perilaku struktur yang berkaitan erat dengan kinerja (Bastian dkk., 2020; Komara dkk., 2019; Mooy dkk., 2020; Oktaviani dkk., 2020; Pertiwi dkk., 2021; Wahyuni dkk., 2016).

Menurut SNI 1726-2019 ada beberapa batasan dan persyaratan tambahan dalam menentukan karakteristik sistem konfigurasi bentuk IB. Prasayarat tersebut tidak lain adalah berdasarkan penerapan kategori desain seismik (KDS) yang mana dibagi berdasarkan kategori kelas layan, berupa A, B, C, D, E dan F berurutan dari KDS rendah tinggi (Badan Standardisasi Nasional, 2019b). Bedasarkan beberapa histori seismik di Indonesia beberapa bangunan dengan mengunakan konsep IB mengalami keruntuhan kritis karena di beberapa titik struktur bangunan terjadi tingkatan lemah berlebih dan lainnya terjadi peningkatan gaya akibat ketidakberaturan. Dari studi dan indikasi tersebut penulis bertujuan untuk menganalisis kapasitas faktor bentuk bangunan IB berbasis kinerja. Pemodelan akan mengambil studi kasus pada bangunan yang sudah ada di kota Surabaya. Hal tersebut menimbang indeks pembangunan IB di kota Surabaya selalu mengalami peningkatan setiap tahunnya (Ngudiyono, 2020).

\section{Ketidakberaturan Bangunan}

Berkembangnya pembangunan konstruksi bentuk komplek menjadi sebuah pilihan paling banyak digunakan karena memiliki tampilan bentuk yang bervariasi mampu melakukan efisiensi penghematan lahan. Bentuk bervariasi pada bangun memiliki sifat yang tidak beraturan mempengaruhi kegagalan struktur. Dalam perencanaan bentuk bangunan komplek harus memiliki perhatian khusus saat melakukan desain dengan mempertimbangkan kekuatan dan keamanan pemodelan bangunan dan sistem bangunan. Ilustrasi konfigurasi bentuk bangunan sesuai (Hirde \& Aher, 2016) dapat dilihat pada Gambar 1.

IB sendiri diketahui sebagai sistem yang tidak memiliki komponen yang tersusun rapi dan seimbang. Struktur IB biasanya bentuknya bersifat informal, lebih modern, terkesan dinamis, progresif serta memiliki nilai lebih dengan adanya suatu yang berbeda pada obyek bangunan dibandingkan pada bangunan kovensional/reguler (Wijaya dkk., 2013). Sebagai tambahan, IB secara sederhana memiliki sifat secara acak dan tidak normal serta terkesan berantakan. Bedasarkan kondisi tersebut, struktur IB memiliki letak titik pusat massa bangunan yang tidak berada ditengah bangunan. Hal ini dapat menimbulkan permasalahan ketidakberaturan kinerja seismik bangunan. Permasalahan kinerja seismik bangunan dapat terjadi terjadi pada bangunan dengan ketidakberaturan konfigurasi yang disebabkan ketidakseragaman respon struktur dalam menerima beban. Untuk mencapai kriteria struktur tahan gempa harus dapat memperhitungkan dampak gaya lateral yang dialami oleh struktur bangunan pada bangunan IB. Bedasarkan SNI 1726-2019 ketidakberaturan struktur bangunan dapat dibedakan menjadi ketidakberaturan vertikal dan horisontal untuk memenuhi kriteria perencanaan. 


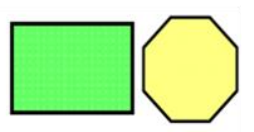

Bentuk reguler
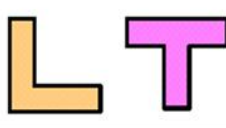

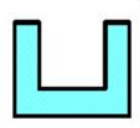

Bentuk irreguler

Gambar 1. Konfigurasi bentuk bangunan (Hirde \& Aher, 2016)

\section{Ketidakberaturan Vertikal}

Ketidakberaturan vertikal merupakan konfigurasi yang terlihat tegak lurus pada arah vertikal dan harus memenuhi persyaratan sesuai SNI 1726-2019. Ketidakberaturan vertikal tersebut di antaranya adalah: (a) ketidakberaturan kekakuan tingkat lunak berlebihan, (b) ketidakberaturan berat massa, (c) ketidakberaturan tingkat lemah berlebihan akibat diskontinuitas pada kekuatan lateral tingkat (Badan Standardisasi Nasional, 2019).

Berdasarkan ketidakberaturan vertikal kondisi (a) dikategorikan apabila terdapat suatu tingkat yang kekakuan lateralnya kurang dari $60 \%$ kekakuan tingkat di atasnya atau nilainya kurang dari $70 \%$ kekakuan rata-rata tiga tingkat di atasnya. Meninjau dari wilayah situs berdasarkan kategori desain seismik (KDS) diposisikan pada KDS D, E dan F. Pada kondisi (b), kategori berdasarkan berat massa dinyatakan tidak beratur apabila massa effektif tingkat lebih dari $150 \%$ massa efektif tingkat didekatnya. Sedangkan pada kondisi (c), dikategorikan apabila kekuatan lateral suatu tingkat kurang dari 65\% kekuatan lateral tingkat di atasnya. Ilustrasi setiap kondisi kekakuan dari (a-c) dapat dilihat pada Gambar 2.

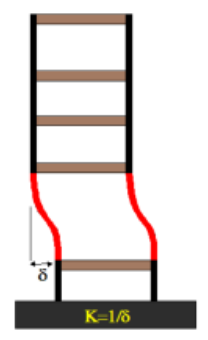

(a)

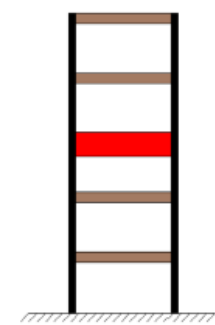

(b)

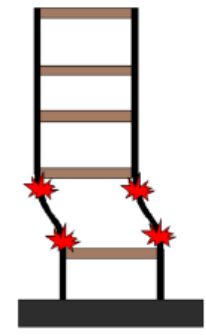

(c)

Gambar 2. Kondisi ketidakberaturan berdasarkan kondisi vertikal; (a) Akibat tingkat lunak berlebih, (b) Akibat berat massa, (c) Akibat diskontinuitas pada kekuatan lateral tingkat (Badan Standardisasi Nasional, 2019)

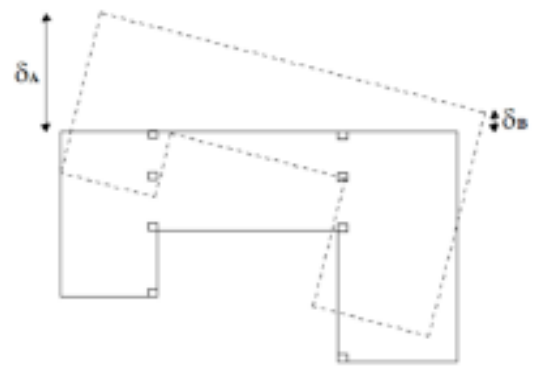

(a)

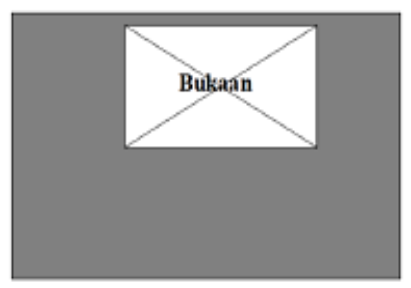

(b)

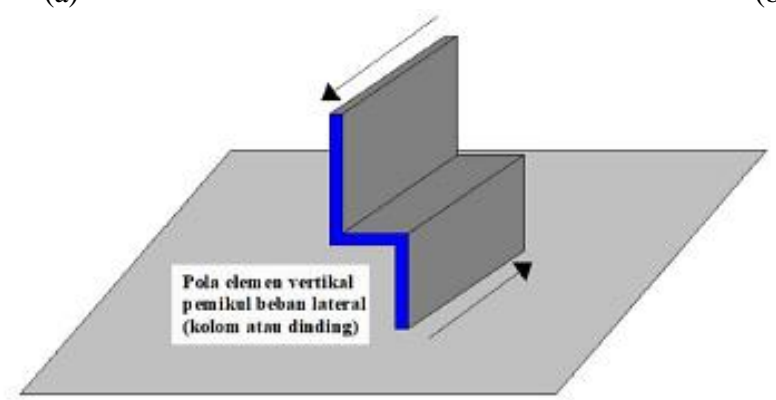

(c)

Gambar 3. Kondisi ketidakberaturan berdasarkan kondisi horizontal; (a) Torsi berlebihan, (b) Diskontinuitas diafragma, (c) Akibat pergeseran tegak lurus terhadap bidang (Badan Standardisasi Nasional, 2019) 


\section{Ketidakberaturan Horizontal}

Ketidakberaturan horizontal dikategorikan apabila memenuhi beberapa kondisi di antaranya yaitu; (1) Torsi berlebihan, (2) diskontunitas diafragma, dan (3) akibat pergeseran tegak lurus terhadap bidang. Semua prasyarat tersebut harus terpenuhi untuk memberikan dukungan kapasitas struktur secara optimal. Ilustrasi setiap kondisi (1-3) dapat dilihat pada Gambar 3.

Pada kondisi (1) misalnya, yang mana merupakan simpangan maksimum yang termasuk dihitung akibat torsi tak terduka pada ujung struktur melintang terhadap sumbu lebih dari 1,4 kali simpangan antarlantai tingkat rata-rata di kedua ujung struktur. Kondisi tersebut terbatas pada diafragma kaku atau setengah kaku pada KDS B, C, D, E dan F. Selanjutnya, pada kondisi (2), diskontinuitas atau variasi kekakuan mendadak, yang mana dibatasi pada daerah yang memiliki bukaan atau void lebih besar dari $50 \%$ pada daerah diafragma bruto tertutup. Hal tersebut bisa dikategorikan juga apabila perubahan kekakuan diafragma efektif lebih dari 50\% dari suatu tingkat ke tingkat selanjutnya. Berdasarkan kondisi tersebut, dapat dikategorikan pada KDS D, E dan F. Terakhir, pada kondisi (3), yaitu ketika terdapat diskontinuitas dalam lintasan tahan gaya lateral, seperti pergeseran tegak lurus terhadap bidang pada setidaknya satu elemen vertikal pemikul gaya lateral. Berdasarkan kondisi tersebut, wilayah situs dapat dikategorikan sama halnya pada kondisi (1).

\section{Konsep Perencanaan Bangunan Tahan Gempa}

Konsep perencanaan struktur bangunan tahan gempa menjadi syarat utama yang harus diperhitungkan kemampuannya dalam memikul beban-beban yang bekerja pada struktur tersebut, di antaranya adalah beban gravitasi dan beban lateral serta beban gempa. Kombinasi beban yang dipakai sesuai Tabel 1. Detail klasifikasi beban mati merujuk pada PPIUG (1987) untuk berat berdasarkan jenis material, elemen struktur utama termasuk beban tangga (Pecker, 2008). Sedangkan, untuk beban hidup mengadopsi SNI 03-1727-2013 dan beban gempa merujuk SNI 1726-2019 (Badan Standarisasi Nasional, 2013). Prosedur analisis sesuai dengan Tabel 2 yang mana memperhatikan setiap unsur ketidakberaturan.

Tabel 1. Kombinasi pembebanan berdasarkan SNI 2847-2019 (Badan Standardisasi Indonesia, 2019a)

\begin{tabular}{|c|c|c|}
\hline No & Tipe kombinasi beban & Keterangan \\
\hline 1 & $1,4 \mathrm{D}$ & \multirow{7}{*}{$\begin{array}{l}\mathrm{U}=\text { Kekuatan perlu } \\
\mathrm{D}=\text { Beban mati } \\
\mathrm{E}=\text { Beban gempa } \\
\mathrm{L}=\text { Beban hidup } \\
\mathrm{Lr}=\text { Beban hidup atap } \\
\mathrm{R}=\text { Beban hujan } \\
\mathrm{W}=\text { Beban angin }\end{array}$} \\
\hline 2 & $1,2 \mathrm{D}+1,6 \mathrm{~L}+0,5(L r$ atau $R)$ & \\
\hline 3 & $1,2 \mathrm{D}+1,6(\mathrm{Lr}$ atau $R)+(1,0 L$ atau $0,5 \mathrm{~W})$ & \\
\hline 4 & $1,2 \mathrm{D}+1,0 \mathrm{~W}+1,0 L+0,5(L r$ atau $R)$ & \\
\hline 5 & $1,2 \mathrm{D}+1,0 E+1,0 L$ & \\
\hline 6 & $0,9 \mathrm{D}+1,0 \mathrm{~W}$ & \\
\hline 7 & $0,9 \mathrm{D}+1,0 E$ & \\
\hline
\end{tabular}

Tabel 2. Prosedur analisis kesesuaian berdasarkan parameter ketidakberaturan KDS berdasarkan SNI 1726-2019

\begin{tabular}{|c|c|c|c|c|}
\hline KDS & Karakteristik struktur & $\begin{array}{l}\text { Analisis } \\
\text { gaya } \\
\text { lateral }\end{array}$ & $\begin{array}{l}\text { Analisis } \\
\text { respon } \\
\text { spektrum }\end{array}$ & $\begin{array}{l}\text { Prosedur } \\
\text { time } \\
\text { history }\end{array}$ \\
\hline $\mathrm{B}$ dan $\mathrm{C}$ & Semua struktur & $\mathrm{I}$ & $\mathrm{I}$ & I \\
\hline \multirow{5}{*}{$\begin{array}{l}\mathrm{D}, \mathrm{E} \\
\text { dan F }\end{array}$} & $\begin{array}{l}\text { Bangunan dengan kategori resiko I atau II yang tidak melebihi } \\
2 \text { tingkat diatas dasar }\end{array}$ & I & I & I \\
\hline & $\begin{array}{l}\text { Struktur tanpa ketidakberaturan structural dan ketinggianya } \\
\text { tidak melebihi } 48,8 \mathrm{~m}\end{array}$ & I & I & I \\
\hline & $\begin{array}{l}\text { Struktur tanpa ketidakberaturan struktur dengan ketinggian } \\
\text { melebihi } 48,8 \mathrm{~m} \text { dan } \mathrm{T}<3,5 \mathrm{Ts}\end{array}$ & I & I & I \\
\hline & $\begin{array}{l}\text { Struktur dengan ketinggian tidak melebihi } 48.8 \mathrm{~m} \text { dan hanya } \\
\text { memiliki ketidakberaturan horizontal tipe } 2,3,4 \text { atau } 5 \text {, atau } \\
\text { ketidakberaturan vertikal tipe } 4,5 \text { a atau } 5 \mathrm{~b}\end{array}$ & I & I & I \\
\hline & Semua struktur lainnya & TI & $\mathrm{I}$ & $\mathrm{I}$ \\
\hline
\end{tabular}




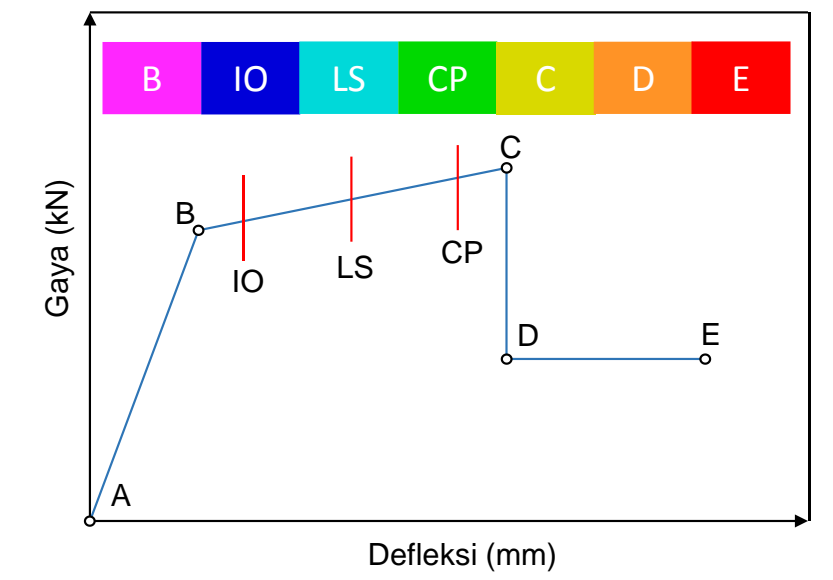

Gambar 4. Kurva kinerja berdasarkan pengaruh gaya dan deformasi

\section{Analisis Kinerja Berdasarkan Direct Displacement Based Design (DDBD)}

Analisis kapasitas adalah evaluasi lanjutan setelah beban servis terpenuhi. Metode dinamik non-linier digunakan menggunakan pendekatan metode ATC-40 (Syarif \& Djauhari, 2019). Evaluasi tersebut untuk mengetahui perilaku struktur sepenuhnya termasuk tingkat kerusakan yang terjadi. Ilustrasi kurva kerusakan dapat dilihat pada Gambar 4. Kondisi kerusakan tersebut diambil berdasarkan kategori sendi plastis pada struktur yang dimodelkan, dimana $B$ atau yield point menunjukan batas linier yang kemudian diikuti terjadinya pelelehan pertama pada struktur. $I O$ - intermediate occupancy merupakan terjadinya kerusakan yang kecil atau tidak berarti pada struktur, kekakuan struktur hampir sama pada saat belum terjadi gempa. $L S$ - life safety merupakan terjadinya kerusakan mulai dari kecil hingga tingkat sedang, kekakuan struktur berkurang tetapi masih mempunyai ambang yang cukup besar terhadap keruntuhan. $C P$ - collapse prevention merupakan terjadinya kerusakan yang parah pada struktur sehingga kekuatan dan kekakuannya berkurang banyak. Selanjutnya $C$ atau kondisi ultimate strength merupakan batas maksimum gaya geser yang masih mampu ditahan gedung sedangkan $D$ atau area residual strength merupakan degradasi kekuatan struktur yang besar, sehingga kondisi struktur tidak stabil dan hampir collapse. Terakhir, $E$ adalah failure point, apabila struktur sudah tidak mampu menahan gaya geser dan hancur.

Batasan simpangan berdasarkan ATC-40 juga dijadikan pertimbangan kapasitas struktur yang mana merujuk pada Tabel 3. Pada tabel tersebut simpangan total adalah simpangan antarlantai/tingkat pada titik kinerja atau pada simpangan maksimum saat atap memasuki performance point dibagi dengan tinggi total seluruh bangunan. Sedangkan, untuk simpangan elastis maksimum adalah proporsi simpangan total di luar leleh efektif. Pada desain bangunan baru, level kinerja yang disarankan adalah kinerja $L S$ dimana pada level kinerja ini bangunan tidak boleh melebihi simpangan total maksimum yaitu lebih dari 0,02 $\mathrm{m}$.

Tabel 3. Batasan Simpangan berbagai level Kinerja Struktur (ATC-40,1996)

\begin{tabular}{|c|c|c|c|c|}
\hline \multirow{2}{*}{ Batasan Simpangan Antar Tingkat } & \multicolumn{4}{|c|}{ Level Kineja Struktur } \\
\cline { 2 - 5 } & $\begin{array}{c}\text { Immediate } \\
\text { Occupancy }\end{array}$ & $\begin{array}{c}\text { Damage } \\
\text { Control }\end{array}$ & Life Safety & $\begin{array}{c}\text { Structural } \\
\text { Stability }\end{array}$ \\
\hline Simpangan Total Maksimum & 0,01 & $0,01-0,02$ & 0,02 & $0.33 \times(\mathrm{Vi} / \mathrm{Pi})$ \\
\hline Simpangan Inelastisitas Maksimum & 0,005 & $0,005-0,0015$ & Tidak dibatasi & Tidak dibatasi \\
\hline
\end{tabular}

Metode DDBD juga ditambahkan dalam menentukan parameter kinerja yang mengacu pada target deformasi. Berdasarkan (Hirde \& Aher, 2016) tahapan awal dalam desain DDBD harus memperhatikan rencana kinerja yang akan dicapai. Agus (2018) menambahkan bahwa batas drift harus diikuti selanjutnya sesuai Persamaan 1. Tahapfan selanjutnya adalah menghitung perpindahan rencana. Menurut Loeding (Pranata, 2007), perpindahan rencana dapat dihitung menggunakan Persamaan $2-4$, sedangkan perpindahan rencana struktur dapat dihitung menggunakan Persamaan 5. 
Tahapan selanjutnya adalah menghitung masa efektif, tinggi efektif dan daktilitas struktur. Parameter yang harus terpenuhi adalah akibat perpindahan SDOF ekuivalen. Perhitungan masa efektif pada SDOF ekuivalen mengikuti Persamaan 6. Sedangkan besarnya perpindahan leleh struktur pada tinggi efektif dapat dihitung dengan Persamaan 7. Lainnya adalah analisis redaman ekuivalen. Nilai redaman ini direkomendasikan oleh (Hirde \& Aher, 2016) adalah sebesar 7\% hingga 10\%. Formulasi nilai redaman menggunakan pendekatan model hysteris Takeda dapat dilihat pada Persamaan 8 .

Waktu getar efektif dan kekauan efektif adalah tahapan analisis lanjutan yang mana dapat dianalisis sesuai Persamaan 9-10 dan 11-12. Pada perencanaan berbasis perpindahan menggunakan kekauan efektif (Keff) atau secant stiffness pada saat perpindahan ultimate $(\Delta \mathrm{u})$ dimana struktur sudah mengalami respon inelastik kurva histeris dapat dimodelkan secara bilinear. Selanjutnya, menghitung gaya geser dasar sesuai Persamaan 13 dan 14.

$$
\begin{aligned}
& \theta d=\theta y+\theta p \leq \theta c \\
& \text { Untuk } \mathrm{n}<4 \text { maka } \Delta i=\theta d . h i \\
& \text { untuk } 4 \leq n<20 \text { maka } \Delta i=\theta d . h i\left[1-\frac{0,5(n-4) h i}{16 h n}\right] \\
& \text { untuk } \mathrm{n} \geq 20 \text { maka } \Delta i=\theta d . h i\left[1-\frac{0,5 h i}{h n}\right]
\end{aligned}
$$

Dimana $\theta d, \theta y, \theta p, \theta c$, secara berurutan adalah drift rencana, leleh, plastis dan maksimum yang diizinkan. Sedangkan, $\Delta i$ adalah perpindahan lateral lantai ke- $i$ dan $n$ adalah jumlah lantai. Sedangkan $h i$ adalah tinggi lantai ke- $i$ dari dasar dan hn adalah tinggi lantai ke- $n$.

$$
\begin{aligned}
& \Delta d=\frac{\sum\left(m i \cdot \Delta i^{2}\right)}{\sum(m i . \Delta i)} \\
& m e=\frac{\sum m i \cdot \Delta i}{\Delta d} \text { dan } h e=\frac{\sum m i \cdot \Delta i \cdot h i}{\sum m i \cdot \Delta i} \\
& \Delta y=\theta y . h e \quad \text { (7) } \quad \xi \text { eff }=\xi_{0}+\xi \text { hyst }=\xi_{0}+\frac{1-\mu^{n\left[\frac{1-r}{\mu}+r\right]}}{\pi} \\
& T e f f=T \frac{\Delta d}{\Delta(T . \xi)}\left[\frac{2+\xi}{7}\right]^{1 / 2} \\
& \text { Teff }=2 \pi \sqrt{\frac{m e}{K e f f}} \\
& \Delta(T . \xi)=\frac{T^{2}}{4 \pi^{2}} S a(T \cdot \xi) \\
& \text { Keff }=\frac{4 \pi^{2} \cdot m e}{T e f f^{2}} \\
& V u=K e f f . \Delta d \\
& F i=\frac{m i \cdot \Delta i}{\sum m i \cdot \Delta i} V
\end{aligned}
$$

dimana $\Delta d$ merupakan perpindahan struktur SDOF ekuivalen dan $m i$ adalah massa lantai ke- $i$. Sedangkan, he merupakan efektif struktur SDOF ekuivalen dan $h i$ adalah tinggi lantai ke-i dari dasar. Selanjutnya $\Delta y$ adalah perpindahan leleh struktur SDOF ekuivalen. Untuk menghitung redaman, nilai $n$ dipakai sebagai faktor degradasi kekakuan dengan nilai 0,5 yang di ikuti oleh nilai $r$ yang merupakan faktor bilinier model dengan nilai 0,05 .

Untuk menghitung waktu getar efektif dan kekakuan efektif yaitu pada Persamaan $9-12$, Teff menyatakan waktu getar efektif dan Keff adalah kekakuan efektif, dimana $T$ merupakan waktu getar dan $\Delta d$ merupakan perpindahan SDOF ekuivalen dengan $\Delta(T . \xi)$ adalah sebagai perpindahan pada $\mathrm{T}$ dan redaman $\xi \%$, dimana $\xi$ adalah redaman struktur ekuivalen. Kemudian, $F i$ adalah besarnya gaya geser yang didistribusikan pada lantai ke- $i$. 
JURNAL ReKayASA KonSTRUKSI MEKANIKA SIPIL (JRKMS)

\section{Hasil dan Pembahasan}

Studi dan analisis struktur dilakukan pada bangunan Attic Showroom Galery yang berlokasi di Surabaya dengan tinggi lantai adalah 11 lantai yang mana tinggi antar lantai adalah $4 \mathrm{~m}$. Mutu beton dan baja yang digunakan berurutan adalah $f^{\prime} c 29 \mathrm{MPa}$ dan fy $400 \mathrm{MPa}$. Bangunan tersebut direncanakan ulang dengan menggunakan dimensi kolom $80 \times 140 \mathrm{~cm}$ dan balok induk $70 \times 80 \mathrm{~cm}$ serta balok anak $40 \times 80 \mathrm{~cm}$. Tebal pelat terpakai adalah $12 \mathrm{~cm}$ termasuk untuk atap. Data bangunan tersebut dijadikan primary data untuk setiap jenis bangunan ireguler lainnya. Modifikasi permodelan dibuat dengan alasan sebagai rekomendasi bagi user dan designer dalam merencanakan bangunan ireguler dengan spesifikasi serupa. Permodelan untuk setiap struktur dapat dilihat pada Gambar 5.

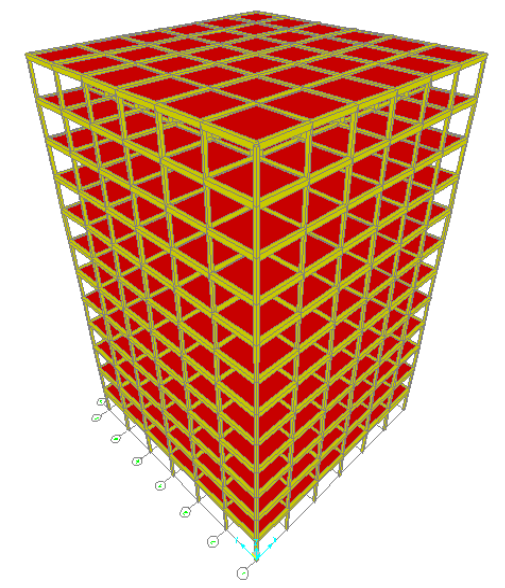

(a)

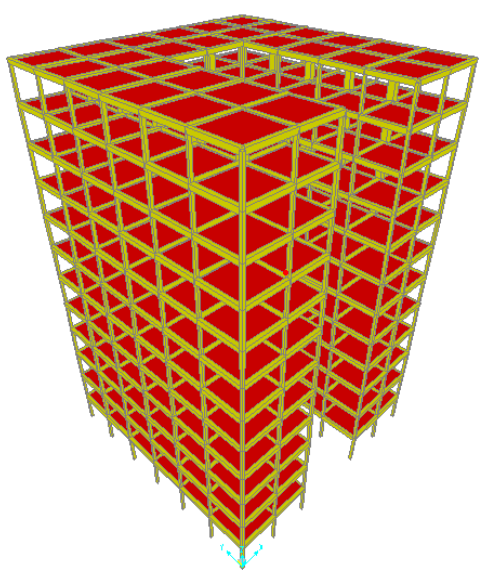

(c)

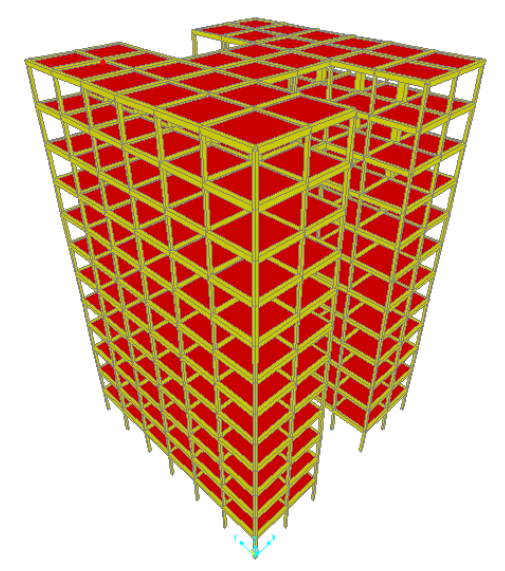

(b)

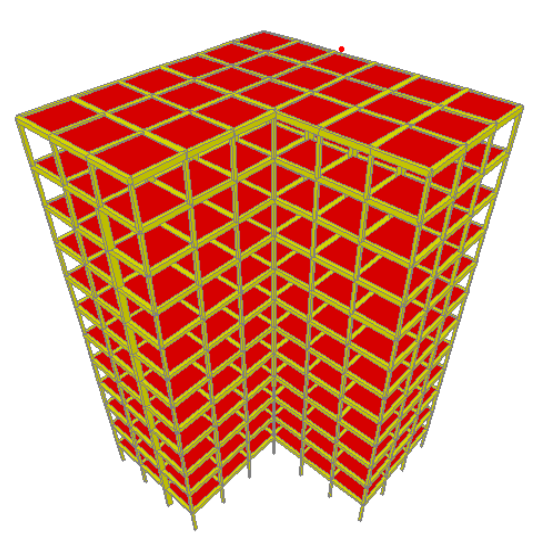

(d)

Gambar 5. Model bangunan ireguler; (a) Bangunan persegi / bangunan kontrol, (b) Bangunan bentuk H, (c) Bangunan bentuk $\mathrm{U}$ dan, (d) Bangunan bentuk $\mathrm{L}$

Apabila kita tinjau Gambar 6, yang merupakan kondisi simpangan setiap lantai untuk arah $x$ dan $y$, tipe $\mathrm{A}, \mathrm{B}$ dan $\mathrm{C}$ relatif lebih stabil jika dibandingkan dengan bentuk bangunan tipe $\mathrm{D}$. Bangunan tipe B memiliki perubahan simpangan yang signifikan untuk arah $x$ dan $y$. Hal tersebut diakibatkan karena bentuk bangunan yang memiliki porsi yang tidak seimbang antara kedua aksis. Titik berat penampang bangunanpun berubah tidak berada pada posisi aksis utama bangunan, sehingga menyebabkan perbedaan yang cukup signifikan. Akan tetapi semua tipe bangunan memenuhi prasyarat simpangan dengan nilai perpindahan tidak melebihi yang disyaratkan yaitu $\Delta y$ lebih kecil dari $\Delta a$ sebesar $80 \mathrm{~mm}$. Rerata simpangan atau perpindahan setiap lantai adalah kurang dari $60 \mathrm{~mm}$.

Berdasarkan identifikasi elemen struktur mengikuti KDS II dengan faktor kekakuan dan koefisien respon adalah 1,0 dan 5,0, setiap tipe bangunan memenuhi kapasitas minimumnya. Berat setiap bangunan memiliki selisih yang tidak jauh berbeda yakni bangunan tipe A sebesar 
$13,9 \times 10^{3}$ ton, tipe $\mathrm{B}$ sebesar $12,5 \times 10^{3}$ ton dan bangunan $\mathrm{C}$ dan $\mathrm{D}$ berurutan sebesar, $12,7 \times 10^{3}$ ton dan $11 \times 10^{3}$ ton. Nilai periode, ragam partisipasi massa dan nilai koefisien respon seismik dapat dilihat pada Tabel 4. Hasil gempa dinamik didapatkan lebih besar daripada gempa statis sehingga memenuhi kondisi bangunan untuk di evaluasi berbasis kinerja menggunakan pendekatan DDBD.
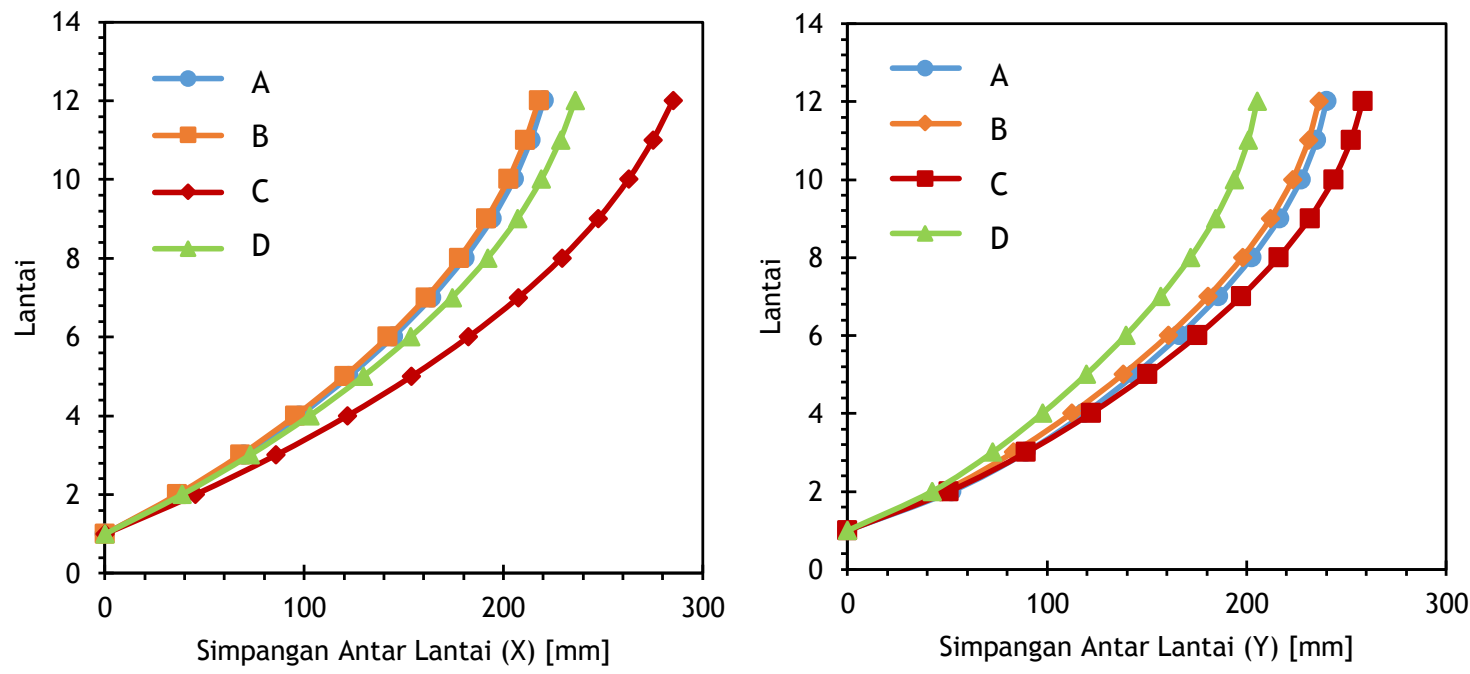

Gambar 6. Nilai drift antar lantai arah x dan y berdasarkan tipe struktur

Tabel 4. Parameter kapasitas struktur berdasarkan tipe bangunan

\begin{tabular}{|c|c|c|c|c|c|c|}
\hline \multirow{2}{*}{$\begin{array}{c}\text { Tipe } \\
\text { Bangunan }\end{array}$} & \multicolumn{6}{|c|}{ Parameter kapasitas } \\
\cline { 2 - 7 } & $\begin{array}{c}\text { Periode } \\
{[\mathrm{sec}]}\end{array}$ & \multicolumn{2}{|c|}{$\begin{array}{c}\text { Partisipasi massa } \\
\text { (x) dan (y) [\%] }\end{array}$} & Cs Pakai & $\begin{array}{c}\text { Gempa } \\
\text { Dinamik [kg] }\end{array}$ & $\begin{array}{c}\text { Gempa } \\
\text { Statik [kg] }\end{array}$ \\
\hline A & 1,630 & 99,7 & 100 & 0,042 & 2.75 .439 & 2.52 .033 \\
\hline B & 1,872 & 99,9 & 100 & 0,042 & 3.68 .225 & 2.53 .019 \\
\hline C & 1,739 & 99,7 & 100 & 0,045 & 2.98 .174 & 2.72 .370 \\
\hline D & 1,783 & 99,7 & 100 & 0,046 & 2.93 .302 & 2.65 .545 \\
\hline
\end{tabular}

Berdasarkan evaluasi parameter yang disampaikan pada Tabel 4, semua tipe struktur memenuhi standar yang disyaratkan. Perbedaan yang cukup signifikan terjadi pada tipe bangunan B yang mana menghasilkan parameter kapasitas lebih besar dibandingkan semua tipe bangunan lain. Tahanan gempa dinamik pun menunjukkan hal yang serupa dengan nilai diatas 350 ton yang mana semua tipe bangunan lain berada dibawah 300 ton.

Sesuai ilustrasi pada Gambar 7, semua kondisi bangunan berdasarkan perbandingan antara base shear vs deflection baik arah $x$ dan $y$ dapat mencapai kapasitas kinerjanya dengan tetap memperhatikan batasan atau kelayakan izin. Profil perpindahan untuk semua tipe kondisi bangunan adalah $0,08 \mathrm{~m}$ dengan nilai faktor, $\theta$ yang diambil dari nilai faktor fase lifesafety adalah 0,02 . Faktor koreksi yang diambil adalah 1,0 yang mana ditentukan dari perbandingan faktor koreksi. Apabila faktor koreksi lebih besar dari 1,0 maka diambil nilai koreksi tersebut. Setiap tipe bangunan harus memenuhi perhitungan perpindahan akibat evaluasi desain DDBD.

Faktor lain yang menentukan adalah redaman efektif yang sejalan dengan besarnya nilai perpindahan. Korelasi dari base shear vs deflection dengan nilai redaman untuk setiap kondisi adalah kurang dari $10 \%$ untuk bangunan tipe A dan lebih besar dari $12 \%$ untuk bangunan tipe $\mathrm{B}, \mathrm{C}$ dan $\mathrm{D}$ yang mana melebihi kapasitas redaman rencana sebesar 5\%. Oleh karena nilai redaman rencana tercapai kekakuan ekuivalen harus di kontrol berdasarkan waktu getar dan periode efektif berbanding dengan gaya geser dalam. Secara umum setiap tipe bangunan memenuhi standar acuan. 

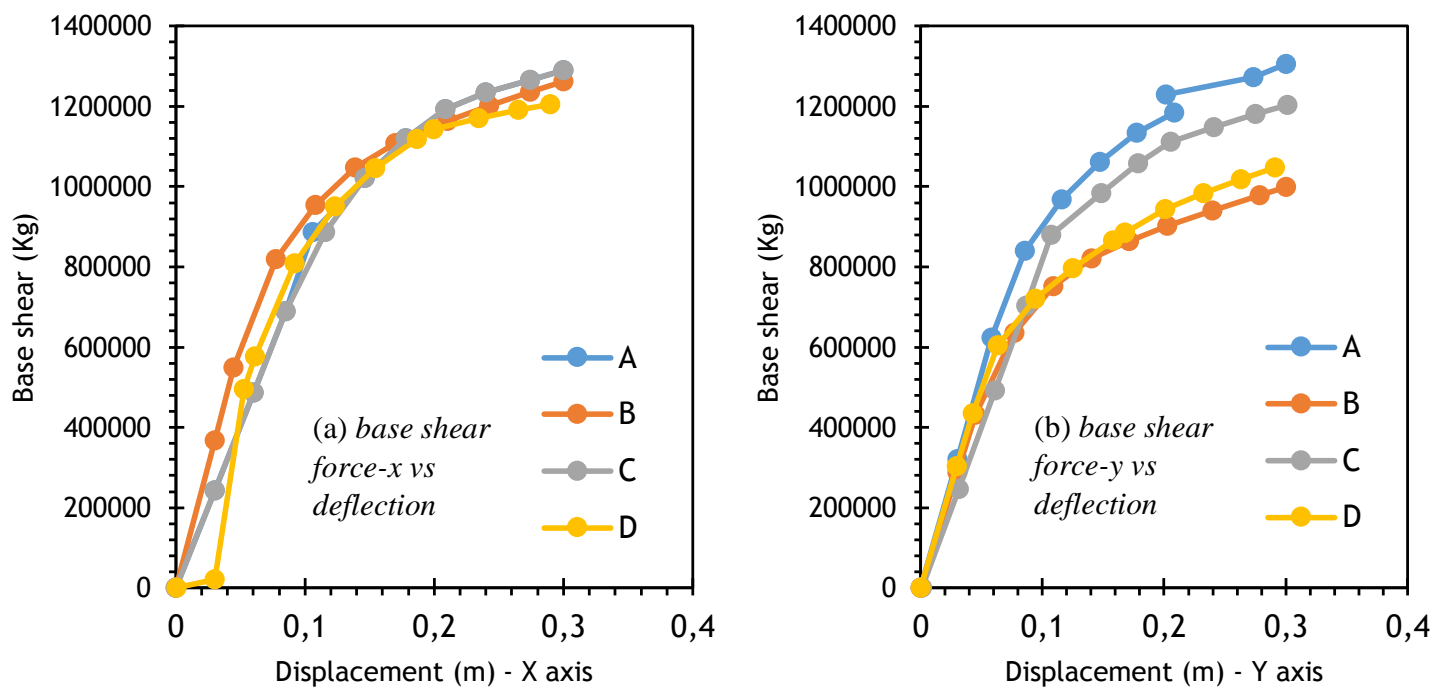

Gambar 7. Nilai drift antar lantai arah x dan y berdasarkan tipe struktur
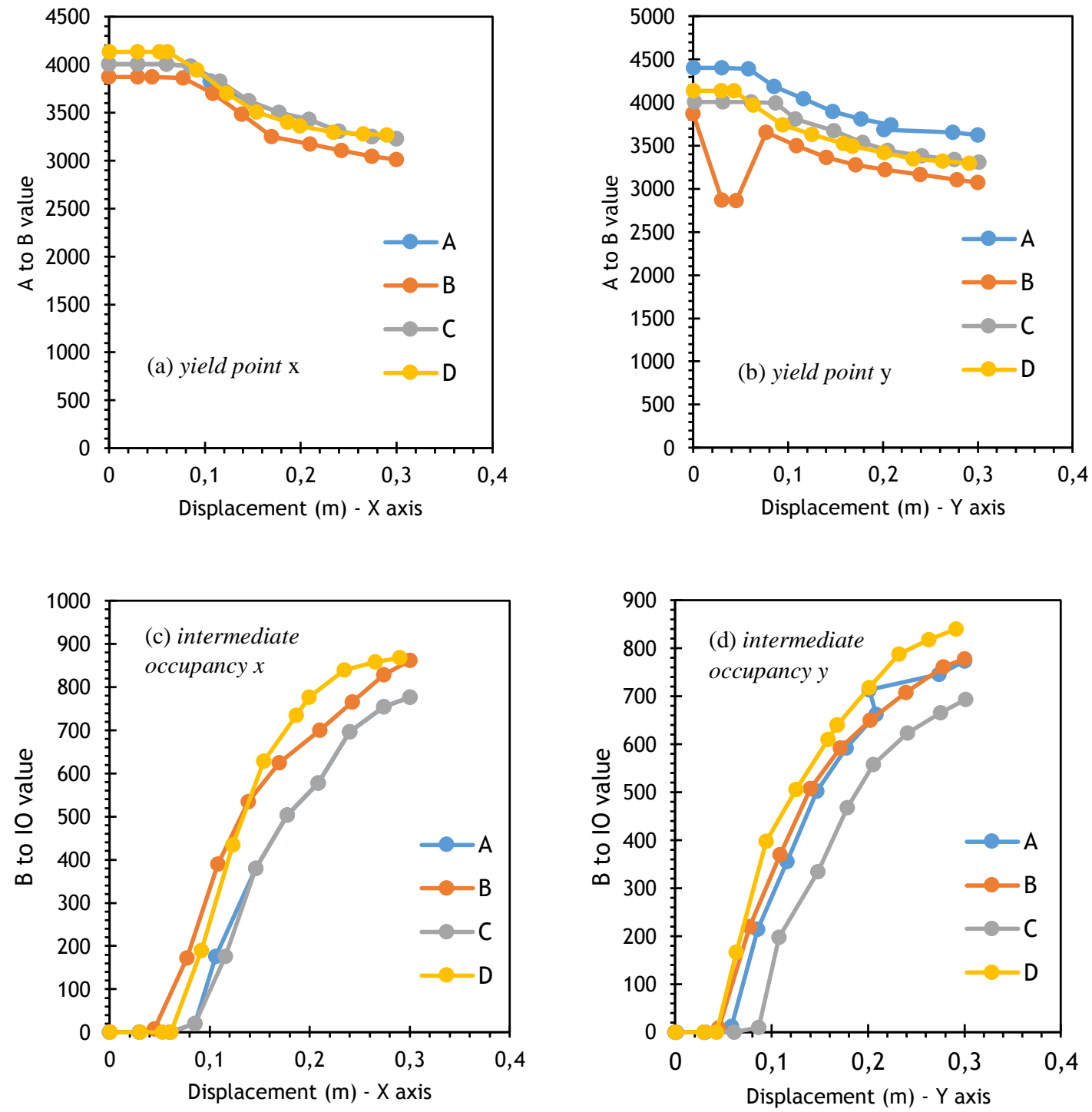

Gambar 8. Level performa berdasarkan evaluasi pushover dengan pendekatan DDBD 
Gambar 8 menjelaskan hasil performance point (PP) yang mana merujuk kesesuaian ATC-40 akibat pengaruh kurva kinerja antara gaya dan deformasi. Step PP yang terjadi pada bangunan tipe A adalah B to IO dengan jumlah titik performa 176 titik untuk arah $x$ dan 214 titik untuk arah $y$ dengan nilai redaman efektif $8 \%$. Deformasi yang dihasilkan masih dalam batasan yang sangat jauh dengan fracture point, sehingga masih dikategorikan sangat aman. Pada bangunan tipe B juga menunjukan step PP yang tidak terpaut jauh dengan kondisi yang sama B to IO yaitu 172 titik untuk arah $x$ dan 220 titik untuk arah $y$. Hanya saja nilai redaman efektif pada kondisi ini meningkat lebih besar menjadi $10 \%$ untuk kedua arah, $x$ dan $y$. Hal ini menunjukan tipe bangunan irregular B bisa meningkatkan redaman efektif sebesar $25 \%$ dari tipe bangunan A.

Kondisi selanjutnya adalah tipe bangunan $\mathrm{C}$ dan D. Pada bangunan tipe $\mathrm{C}$ kondisi $\mathrm{B}$ to IO juga menjadi titik akhir dengan nilai jumlah titik peforma ralatif lebih kecil dibandingkan tipe bangunan A dan B, yaitu 20 titik untuk arah $x$ dan 198 titik untuk arah $y$. Perbedaan yang signifikan tersebut tidak lain terjadi akibat ketidakberaturan bentuk yang dominan ke arah $y$ dibandingkan kea rah $x$. Karena terjadi ketidakberaturan yang dominan, sehingga nilai redaman efektifpun menurun yaitu dibawah 5\% untuk kedua arah. Terakhir, tipe bangunan D, PP masih menunjukan B to IO. Jumlah titik peforma pada titik $x$ dan $y$ secara berurutan adalah 190 titik dan 166 titik. Nilai redamanpun memiliki nilai yang sama dengan tipe bangunan $C$ yaitu sama dengan atau lebih kecil dari 5\%. Batasan redaman efektif maksimal untuk semua kondisi bangunan adalah $29 \%$ yang mana, setiap bangunan masih memenuhi persyaratan. Evaluasi DDBD dengan level kinerja sesuai ATC-40 dapat dilihat pada Tabel 5.

Tabel 5. Evaluasi kinjerja struktur dengan pendekatan DDBD mengadopsi desain ATC-40

\begin{tabular}{|c|c|c|c|c|c|}
\hline \multirow{3}{*}{$\begin{array}{c}\text { Tipe } \\
\text { Struktur }\end{array}$} & \multirow{3}{*}{ Parameter } & \multicolumn{4}{|c|}{ Kinerja DDBD berdasarkan ATC-40 } \\
\hline & & \multicolumn{2}{|c|}{$x$-axis } & \multicolumn{2}{|c|}{$y-$ axis } \\
\hline & & Rencana & Aktual & Rencana & Aktual \\
\hline \multirow{3}{*}{ A } & Target Perpindahan & 0,48838 & 0,28 & 0,48838 & 0,3 \\
\hline & Drift aktual & - & 0,00636 & - & 0,00682 \\
\hline & Level Kinerja & LS & $\mathrm{IO}$ & LS & IO \\
\hline \multirow{3}{*}{ B } & Target Perpindahan & 0,48837 & 0,3 & 0,48837 & 0,31 \\
\hline & Drift aktual & - & 0,00682 & - & 0,00705 \\
\hline & Level Kinerja & LS & $\mathrm{IO}$ & LS & $\mathrm{IO}$ \\
\hline \multirow{3}{*}{$\mathrm{C}$} & Target Perpindahan & 0,48736 & 0,31 & 0,48736 & 0,32 \\
\hline & Drift aktual & - & 0,00705 & - & 0,00727 \\
\hline & Level Kinerja & LS & $\mathrm{IO}$ & LS & $\mathrm{IO}$ \\
\hline \multirow{3}{*}{$\mathrm{D}$} & Target Perpindahan & 0,4864 & 0,29 & 0,4864 & 0,292 \\
\hline & Drift aktual & - & 0,00659 & - & 0,00664 \\
\hline & Level Kinerja & LS & $\mathrm{IO}$ & LS & IO \\
\hline
\end{tabular}

Catatan: LS = life safety, IO = Intermediate occupancy

Distribusi sendi plastis untuk setiap bangunanpun relatif menunjukkan perilaku yang sama karena semua bangunan tersebut memiliki berat bangunan dan konsep struktur yang sejenis. Tipe permodelanpun dibuat sama yang membedakan hanya kondisi ketidakberaturan. Walaupun kondisi kegagalan pada B to IO untuk semua tipe bangunan yang artinya menunjukan yield point sama, nilai deformasi dan tahanan kapasitas atau gaya berbeda satu sama lain. Sesuai Tabel 5, kondisi kinerja struktur mengalami kenaikan setelah dilakukan evaluasi berbasis push over analysis yang mana pada konsep desain rencana kinerja struktur melampaui batasan B to IO yakni pada kondisi LS. Sehingga dengan perencanaan kapasitas struktur berbasis DDBD bisa dikatakan struktur mampu memberikan dukungan kapasitas dengan baik dengan nilai kapasitas sisa yang masih berada pada kondisi aman dan mampu menahan kapasitas dengan baik.

\section{Kesimpulan}

Makalah ini menunjukan secara sistematis analisis struktur dengan parameter ketidakberaturan dengan metode numerik dan teoritis. Pendekatan analisis dibuat berdasarkan parameter berat struktur yang kemudian ditinjau dengan konsep ketidakberaturan yang umum diterapkan pada 
bangunan konstruksi. Beberapa hasil dari analisis yang dilakukan dapat disimpulkan sebagai berikut:

a. Perilaku simpangan elemen struktur untuk setiap kondisi bangunan masih memenuhi persyaratan minimum dengan nilai simpangan elemen terbesar ditunjukan pada bangunan tipe $\mathrm{D}$ dengan nilai $260 \mathrm{~mm}$ pada $y$-axis. Kemudian, diikuti nilai drift struktur secara menyeluruh pada tipe bangunan yang sama dengan nilai sebesar $486 \mathrm{~mm}$.

b. Parameter kapasitas struktur yang meliputi, distribusi momen pada elemen struktur, periode, waktu getar alami dan redaman masih memenuhi kapasitas minimum untuk semua tipe bangunan yakni masih dibawah nilai $29 \%$ nilai redaman efektif.

c. Bangunan tipe A dan B relatif lebih menunjukan perilaku yang sama baik dari perbandingan base shear vs deflection hingga perilaku performa. Sedangkan bangunan tipe $C$ dan D lebih tipikal satu sama lain yang nilainya terpaut sedikit lebih kecil dari tipe bangunan A dan B. Hal tersebut dikarenakan persentase nilai parameter kapasitas yang sejalan dengan faktor bentuk bangunan $\mathrm{C}$ dan $\mathrm{D}$ yang tidak simetri antara $x$-axis dan $y$ axis.

d. Kinerja struktur DDBD berdasarkan pendekatan ATC-40 menunjukan peningkatan yang mana performa pada kondisi rencana lebih besar dibandingkan kondisi aktual, yang artinya masih mampu memberikan kinerja yang baik dengan kondisi pembebanan yang diberikan. Pada kondisi rencana setiap struktur masuk pada level performa lifesafety sedangkan setelah evaluasi kinerja struktur memasuki level performa intermediate occupancy dengan nilai target perpindahan yang lebih kecil.

\section{Referensi}

Agus (2018). Analisis Perbandingan Kolom Berbentuk Bulat Dan Persegi Terhadap Kinerja Struktur Gedung Beton Bertulang Akibat Beban Gempa ( Studi Kasus Gedung BKPSDM Kota Padang Panjang). Jurnal Momentum, 20(2), 102-109.

Badan Standardisasi Nasional. (2019). SNI 2847-2019: Persyaratan beton struktural untuk bangunan gedung dan penjelasan.

Badan Standardisasi Nasional. (2019). SNI 1726-2019: Tata cara perencanaan ketahanan gempa untuk struktur bangunan gedung dan non gedung.

Badan Standardisasi Nasional. (2013). SNI 1727-2013: Beban minimum untuk perancangan bangunan gedung dan struktur lain.

Bastian, M. A., Tambusay, A., Komara, I., Sutrisno, W., Irawan, D., \& Suprobo, P. (2020). Enhancing the Ductility of a Reinforced Concrete Beam using Engineered Cementitious Composite. IOP Conference Series: Earth and Environmental Science, 506, 012044. https://doi.org/10.1088/1755$1315 / 506 / 1 / 012044$

Hirde, S., \& Aher, R. (2016). Seismic Evaluation of Irregular Structures. Issue: Special, 3(5), 750-755.

Komara, I., Wahyuni, E., Suprobo, P., \& Taskin, K. (2018). Assessing the tensile capacity of coldformed steel connections using self-drilling screws and adhesive materials. International Journal on Advanced Science, Engineering and Information Technology, 8(2). https://doi.org/10.18517/ijaseit.8.2.4314

Komara, I., Wahyuni, E., Suprobo, P., \& Taşkin, K. (2019). Micro-Structural Characterization of the bond strength capacity of adhesive material in the alternative of cold-formed steel frame system. IOP Conference Series: Materials Science and Engineering, 462(1). https://doi.org/10.1088/1757$899 \mathrm{X} / 462 / 1 / 012004$

Komara, Indra, Tambusay, A., Sutrisno, W., \& Suprobo, P. (2019). Engineered Cementitious Composite as an innovative durable material: A review. ARPN Journal of Engineering and Applied Sciences, 14(4), 822-833.

Komara, Indra, Taşkin, K., Wahyuni, E., \& Suprobo, P. (2017). Experiment on Cold-Formed Steel CSection Joint With Screw ond Adhesive Material. MATTER: International Journal of Science and Technology, 3(2), 51-63. https://doi.org/https://dx.doi.org/10.20319/mijst.2017.32.5163 EXPERIMENT

Komara, Indra, Wahyuni, E., \& Suprobo, P. (2017). A study on Cold-formed Steel Frame Connection: A review. IPTEK, The Journal for Technology and Science, 28(3), 83-89.

Kumar, C. M. R., Manjunatha, H. B., Channappa, T. M., \& Prashanth, M. H. (2011). Seismic Performance Evaluation of Irregular RC Buildings with Mass Irregularity. In International Conference on Earthquake Analysis and Design of Structures (EQADS 2011).

Mooy, M., Tambusay, A., Komara, I., Sutrisno, W., Faimun, \& Suprobo, P. (2020). Evaluation of Shear- 
Critical Reinforced Concrete Beam Blended with Fly Ash. IOP Conference Series: Earth and Environmental Science, 506, 012041. https://doi.org/10.1088/1755-1315/506/1/012041

Nareswarananindya, Laksono, S. H., Ramadhani, A. N., Budianto, A., Komara, I., \& Syafiarti, A. I. D. (2021). The design concept of bamboo in micro housing as a sustainable self-building material. IOP Conference Series: Materials Science and Engineering, 1010, 012026. https://doi.org/10.1088/1757-899x/1010/1/012026

Ngudiyono, N. (2020). Perhitungan Beban Gempa Statik Ekivalen SNI 1726-2019. April.

Oktaviani, W. N., Tambusay, A., Komara, I., Sutrisno, W., Faimun, F., \& Suprobo, P. (2020). Flexural Behaviour of a Reinforced Concrete Beam Blended with Fly ash as Supplementary Material. IOP Conference Series: Earth and Environmental Science, 506, 012042. https://doi.org/10.1088/1755$1315 / 506 / 1 / 012042$

Pecker, A. (Ed.). (2008). Advanced earthquake engineering analysis (Vol. 494). Springer Science \& Business Media.

Pertiwi, D., Komara, I., \& Fristian, R. (2021). Design concept of reinforced concrete beams with large web openings. IOP Conference Series: Materials Science and Engineering, 1010, 012039. https://doi.org/10.1088/1757-899x/1010/1/012039

Prakosa, A. Y., \& Wibowo, A. (2018). Desain Rekayasa Gempa Berbasis Kinerja Dengan Metode Direct Displacement Based Design (DDBD). Jurnal Mahasiswa Jurusan Teknik Sipil, 1(2), 890-898 http://sipil.studentjournal.ub.ac.id/index.php/jmts/article/view/706

Pranata, Y. A. (2007). Studi Perencanaan Berbasis Perpindahan: Metode Direct-Displacement Based Design Studi Kasus pada Rangka Beton Bertulang Bertingkat Rendah. Jurnal Teknik Sipil Universitas Atma Jaya Yogyakarta, 7(2), 99-118.

Susanti, E., Istiono, H., Komara, I., Pertiwi, D., \& Septiarsilia, Y. (2021). Effect of fly ash to watercement ratio on the characterization of the concrete strength. IOP Conference Series: Materials Science and Engineering, 1010, 012035. https://doi.org/10.1088/1757-899x/1010/1/012035

Syarif, H. A., \& Djauhari, Z. (2019). Respon Struktur Sistem Flat Slab-Drop Panel Pada Gedung Bertingkat Tak Beraturan Terhadap Beban Gempa dengan Analisis Respon Spektrum. Aplikasi Teknologi (APTEK), 11(2), 97-104.

Wahyuni, E., Istiono, H., Iranata, D., \& Komara, I. (2016). Non-linear analysis of failure mechanism of steel truss bridge. ARPN Journal of Engineering and Applied Sciences, 11(24), 14373-14382.

Wijaya, C., Wijaya, S. W., Muljati, I., \& Pudjisuryadi, P. (2013). Evaluasi Kinerja Direct DisplacementBased Design Dan Force Based Design Bangunan Irregular Plan 6-Lantai. Jurnal Dimensi Pratama Teknik Sipil, 2(2)., 1-8.

Wisnumurti, I. C. dan A. A. (2013). Analisis Pushover Pada Gedung Tidak Beraturan Dengan Study Kasus Pada Gedung Baru Fia Unibraw. Journal of Chemical Information and Modeling, 53(9), 1689-1699. https://doi.org/10.1017/CBO9781107415324.004 


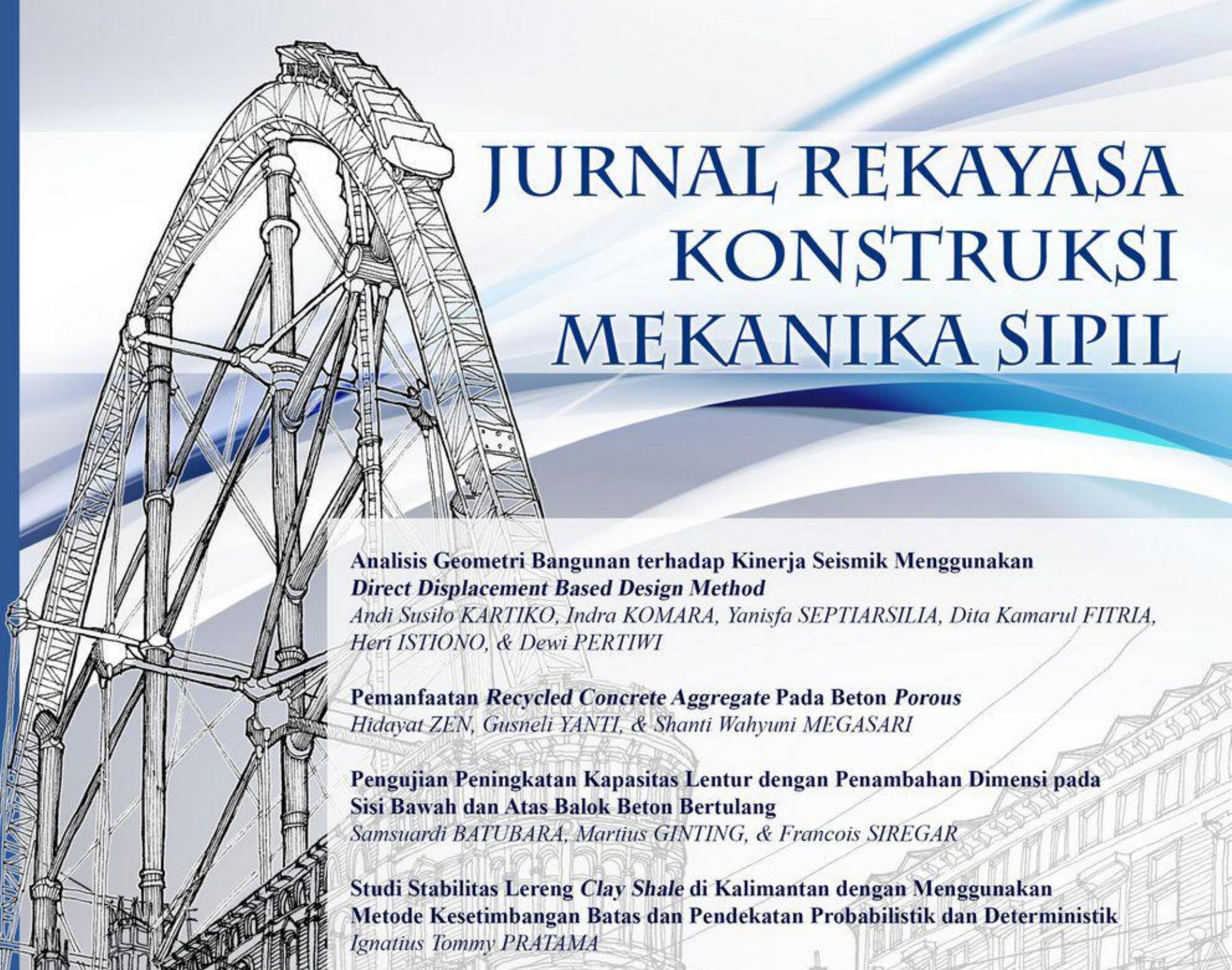

Pengaruh Tata Guna Lahan terhadap Kinerja Jalan dan Biaya Tundaan Lalu Lintas Koridor Jalan GOR Mustika Kabupaten Blora

Hartono Guntur RISTIYANTO \& Salma MFIRDAUS

Kinerja Moda Bus Trans Mebidang Trayek Lubuk Pakam-Pusat Pasar Medan di Masa Pandemi Covid-19

Oloan SITOHANG, Reynaldo SIAHAAN, \& Arnoldus Yansen Berkat LAIA

Perbandingan Produktivitas Tenaga Kerja Pembesian dan Bekisting Saat Jam Kerja Normal dan Lembur Menggunakan Metode Productivity Rating Caroline Maretha SUJANA \& Raka Aditya HAKIM

Analisis Faktor-Faktor yang Mempengaruhi Produktivitas Tenaga Kerja pada Proyek Pembangunan Jalan Tol Ruas Binjai-Langsa Seksi Binjai-Pangkalan Brandan Yolanda Ayu DAMAYANTI \& Mizanuddin SITOMPUL

Fakultas Teknik 


\section{Jurnal Rekayasa Konstruksi Mekanika Sipil (JRKMS)}

Jurnal Rekayasa Konstruksi Mekanika Sipil (JRKMS) Fakultas Teknik Universitas Katolik Santo Thomas berisi artikel-artikel ilmiah yang meliputi kajian di bidang teknik khususnya Teknik Sipil, seperti matematika teknik, mekanika teknik, analisis struktur, konstruksi baja, konstruksi beton, konstruksi kayu, konstruksi gelas, mekanika tanah, teknik pondasi, hidrologi, hidrolika, bangunan air, manajemen konstruksi, dinamika struktur, earthquake engineering, sistem dan rekayasa transportasi, ilmu ukur tanah, struktur bangunan sipil, rekayasa jalan raya, serta penelitian-penelitian lain yang terkait dengan bidang-bidang tersebut.

Terbit dalam 2 (dua) kali setahun yaitu pada bulan April dan September

\section{Penasihat :}

Prof. Dr. Drs. Sihol Situngkir, MBA. (Rektor Universitas Katolik Santo Thomas)

Ketua Penyunting (Editor in Chief) :

Ir. Oloan Sitohang, M.T. (Universitas Katolik Santo Thomas)

Manajer Penyunting (Managing Editor):

Reynaldo, S.T., M.Eng. (Universitas Katolik Santo Thomas)

\section{Anggota Penyunting (Editorial Board):}

Dr.-Ing. Sofyan S.T, M.T. (Universitas Malikussaleh)

Ir. Martius Ginting, M.T. (Universitas Katolik Santo Thomas)

Samsuardi Batubara, S.T., M.T. (Universitas Katolik Santo Thomas)

Dr. Janner Simarmata (Universitas Negri Medan)

\section{Mitra Bestari (Peer Reviewer):}

Dr.Eng. Ir. Aleksander Purba, S.T., M.T., IPM, ASEAN Eng. (Universitas Lampung, Indonesia)

Ir. Binsar Silitonga, M.T. (Universitas Katolik Santo Thomas, Indonesia)

Budi Hasiholan, S.T., M.T., Ph.D (Institut Teknologi Bandung, Indonesia)

Ir. Charles Sitindaon, M.T. (Universitas Katolik Santo Thomas, Indonesia)

Dr. Erica Elice Uy (De La Salle University, Philippines)

Dr. Ernesto Silitonga, S.T, D.E.A. (Universitas Negeri Medan, Indonesia)

Prof. Dr-Ing. Johannes Tarigan (Universitas Sumatera Utara, Indonesia)

Linda Prasetyorini (Universitas Brawijaya, Malang, Indonesia)

Dr.Eng. Mia Wimala (Universitas Katolik Parahyangan, Indonesia)

Dr.Eng. Minson Simatupang (Universitas Halu Oleo, Indonesia)

Dr. Mochamad Raditya Pradana (Keppel Marine and Deepwater Technology, Singapura)

Dr. Ir. Shirly Susanne Lumeno, S.T., M.T. (Universitas Negeri Manado, Indonesia)

Dr. Senot Sangadji (Universitas Sebelas Maret, Indonesia)

Ir. Simon Dertha, M.T. (Universitas Katolik Santo Thomas, Indonesia)

Dr. Thi Nguyên Cao (Tien Giang University, Viet Nam)

Budijanto Widjaja, S.T., M.T., Ph.D, (Guest Vol.4.No.2) (Universitas Katolik Parahyangan, Indonesia)

\section{Ilustrator Sampul:}

Yulianto, ST., M.Eng

\section{Penerbit \& Alamat Redaksi:}

Fakultas Teknik Universitas Katolik Santo Thomas

Jl. Setiabudi No. 479-F Tanjung Sari, Medan 20132

Telp. (061) 8210161 Fax : (061) 8213269

email : unika.sipil@yahoo.com 


\title{
Konten
}

\author{
REKAYASA STRUKTUR \\ Analisis Geometri Bangunan terhadap Kinerja Seismik Menggunakan \\ Direct Displacement Based Design Method \\ Andi Susilo KARTIKO, Indra KOMARA, Yanisfa SEPTIARSILIA, Dita Kamarul \\ FITRIA, Heri ISTIONO, \& Dewi PERTIWI
}

hal.

$73-84$

Pemanfaatan Recycled Concrete Aggregate Pada Beton Porous

Hidayat ZEN, Gusneli YANTI, \& Shanti Wahyuni MEGASARI

Pengujian Peningkatan Kapasitas Lentur dengan Penambahan Dimensi

pada Sisi Bawah dan Atas Balok Beton Bertulang

Samsuardi BATUBARA, Martius GINTING, \& Francois SIREGAR

\section{REKAYASA GEOTEKNIK}

Studi Stabilitas Lereng Clay Shale di Kalimantan dengan Menggunakan

Metode Kesetimbangan Batas dan Pendekatan Probabilistik dan

Deterministik

Ignatius Tommy PRATAMA

\section{REKAYASA TRANSPORTASI}

Pengaruh Tata Guna Lahan terhadap Kinerja Jalan dan Biaya Tundaan

Lalu Lintas Koridor Jalan GOR Mustika Kabupaten Blora

Hartono Guntur RISTIYANTO \& Salma M FIRDAUS

Kinerja Moda Bus Trans Mebidang Trayek Lubuk Pakam-Pusat Pasar

Medan di Masa Pandemi Covid-19

Oloan SITOHANG, Reynaldo SIAHAAN, \& Arnoldus Yansen Berkat LAIA

\section{MANAJEMEN KONSTRUKSI}

Perbandingan Produktivitas Tenaga Kerja Pembesian dan Bekisting Saat Jam Kerja Normal dan Lembur Menggunakan Metode Productivity Rating Caroline Maretha SUJANA \& Raka Aditya HAKIM

Analisis Faktor-Faktor yang Mempengaruhi Produktivitas Tenaga Kerja pada Proyek Pembangunan Jalan Tol Ruas Binjai-Langsa Seksi BinjaiPangkalan Brandan

Yolanda Ayu DAMAYANTI \& Mizanuddin SITOMPUL 


\section{Pengantar Redaksi}

Puji dan syukur kami sampaikan kepada Tuhan Yang Maha Esa karena atas kasih karuniaNYA kami dapat menyelesaikan penerbitan Jurnal Rekayasa Konstruksi Mekanika Sipil (JRKMS) Volume 4 Nomor 2, di bulan September tahun 2021 ini. Jurnal ini fokus pada beragam subbidang dalam Teknik Sipil antara lain Rekayasa Struktur, Rekayasa Geoteknik, Rekayasa Transportasi, Teknik Sumber Daya Air, dan Manajemen Konstruksi. Namun, tidak menutup kesempatan bagi subbidang lainnya yang berkaitan dengan keilmuan Teknik Sipil.

Satu hal yang patut disyukuri pula adalah semakin terkendalinya kondisi pandemi COVID-19 di Indonesia. Hal ini turut menjadi angin segar pendorong bagi kita untuk meningkatkan semangat meneliti dan berkontribusi pada bidang keilmuan kita. Pada edisi ini, kami menerima banyak artikel dengan topik yang menarik. Ada 8 peer-reviewed artikel yang terbit di Volume 4 Nomor 2 ini, yang mana terdiri atas 3 (tiga) artikel dalam topik Rekayasa Struktur, 1 (satu) artikel dalam topik Rekayasa Geoteknik, 2 (dua) artikel dalam topik Rekayasa Transportasi, 2 (dua) artikel dalam topik Manajemen Konstruksi.

Seiring dengan semakin tingginya tuntutan kualitas publikasi ilmiah oleh pemerintah, pada edisi ini tim editorial berusaha meningkatkan kualitas review dan penyuntingan dengan harapan semakin baik pula kapasitas kita bersama, dan kualitas artikel ilmiah yang kita terbitkan. Dewan redaksi menyampaikan apresiasi tinggi kepada para penulis yang tulisannya diterbitkan pada volume ini, atas kerja samanya merespon komentar dan rekomendasi dari tim editorial dan mitra bestari. Kami menyadari bahwa butuh dedikasi dan investasi waktu untuk menghasilkan karya tulis yang baik dan bermanfaat. Terkhusus, kami bersyukur atas para mitra bestari yang tidak pernah lelah dalam menyambut permintaan kami dengan penuh dedikasi.

Sebagai penutup, harapan kami adalah semoga jurnal ini dapat menjadi media ilmiah yang bermanfaat dan informatif bagi rekan-rekan dan praktisi bidang ketekniksipilan di Indonesia. Salam hangat dan Salam sehat.

Medan, September 2021

Tim Editorial 
